\title{
Il complesso ligneo dell'abbazia di Rodengo: il leggio di fra Raffaele
}

\author{
Massimo De Paoli \\ Luca Ercolin
}

Abstract

La congregazione dei monaci Olivetani costituì anche - stante il motto benedettino ora et labora per molti frati vocati alla lavorazione del legno, l'occasione di apprendistato nell'arte dell'intarsio e dell'intaglio: l'apprendimento dei fondamenti di tale arte (la scelta dei legni, la loro trattazione con sostanze impregnanti, il taglio e l'incastro dei listelli, l'uso dei mastici, ecc.) costituiva il denominatore comune di ognuno di loro.

Questo è il filo rosso che lega fra Sebastiano da Rovigno, fra Giovanni, fra Raffaele e tutti coloro che nel tempo hanno arricchito chiese e abazie di arredi liturgici sapientemente intarsiati e intagliati.

II presente contributo propone un'inedita lettura architettonica e il rilievo laser scanner 3d del badalone ligneo -opera di fra Raffaele- dell' abazia di Rodengo , attualmente custodito nella pinacoteca Tosio Martinengo di Brescia e un'analisi comparata dello stesso con il badalone della chiesa di Santa Maria in organo in Verona, opera di fra Giovanni maestro di fra Raffaele e con il leggio di Monte Oliveto Maggiore a Siena intagliato e intarsiato dall'allievo bresciano al fine di evidenziare analogie e differenze fra queste importanti opere olivetane.

Parole chiave

leggio, badalone, tarsia, fra Raffaele, olivetani.

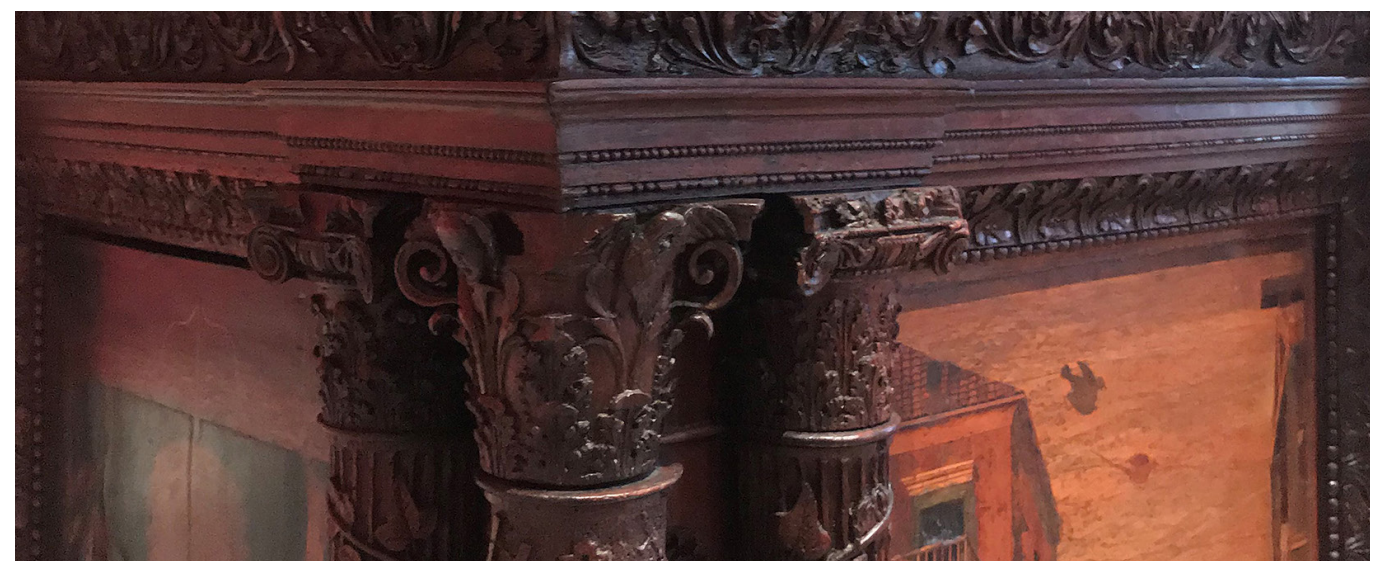




\section{II coro ligneo e il leggio}

Il complesso ligneo di Rodengo fu smembrato nell'Ottocento a causa della vendita al comune di Brescia, nel I868, del leggio ora custodito nella Pinacoteca Tosio Martinengo.

Per anni gli studiosi, soprattutto locali, hanno attribuito a fra Raffaele sia il coro sia il leggio [I] e solo nel 1963 il Lorenzoni prowide a richiamare l'attenzione su quanto aveva scritto il Finocchietti quasi un secolo prima [2] e ad attribuire il coro a Cristoforo Rocchi, prestigioso magister a lignamine, cioè intarsiatore, intagliatore, ma anche marangone ed architetto proveniente da Pavia [3].

Le tarsie dei dossali del Rocchi evidenziano una certa "discrepanza tra le linee e gli elementi decorativi goticheggianti dell'intaglio e le architetture nelle cartelle intarsiate che ornano i dossali" [Anelli 1987, p. 46]. Differenza dovuta probabilmente a un disegno del coro predisposto dai monaci olivetani consegnato al Rocchi, come testimoniano le fonti documentarie analizzate da Passamani, e contrario alla adesione del maestro ai nuovi canoni dell'architettura. II Passamani sostiene inoltre che il pagamento piuttosto elevato farebbe pensare a un intervento anche progettuale e non solo di mera traduzione materiale del disegno da parte del Rocchi. La definizione formale delle architetture intarsiate nei dossali (fig. 2) testimonia lo sforzo, proprio dell'artista non meno che dei monaci, di passare dai modelli più antichi, probabilmente raffigurati nel disegno degli olivetani, alla soluzione più moderna proposta dal maestro pavese. Rocchi, intagliatore ma anche architetto, può aver fornito, alla fine del $\mathrm{XV}$ secolo, indicazioni riguardanti il badalone, in seguito realizzato da fra Raffaele. La forte

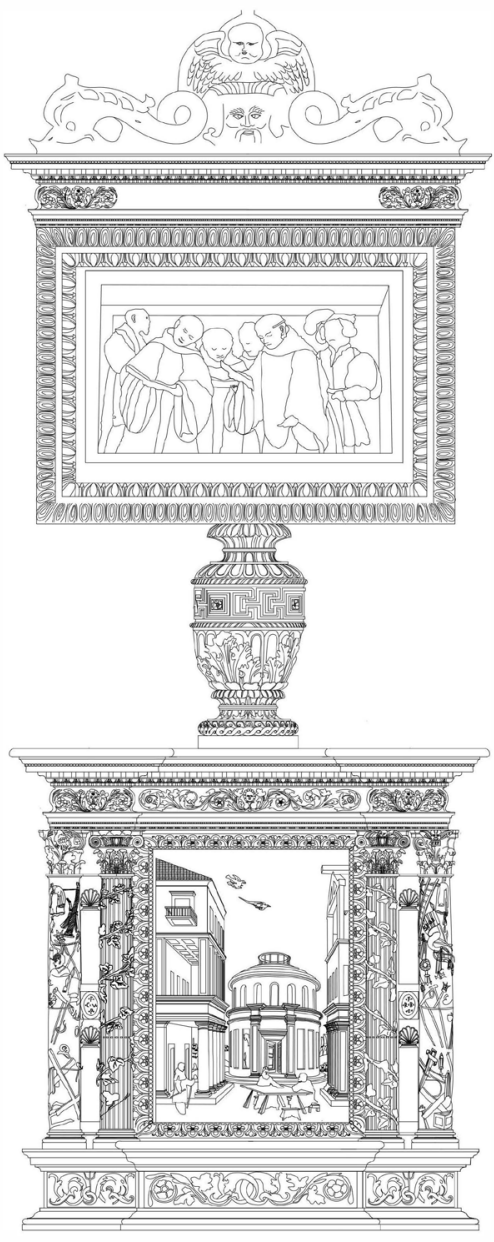


connotazione architettonica del leggio di Rodengo induce a ipotizzare la presenza di un architetto o di precise indicazioni riguardanti l'uso degli ordini architettonici che fra la fine del Quattrocento e gli inizi del Cinquecento circolavano nelle tavole illustrate dei trattati e costituivano il repertorio formale tramite il quale si arricchiva di nuove possibilità ogni architetto, scultore, pittore o artigiano.

Anche la differenza fra i legni impiegati per le tarsie del coro, di essenze diverse ma tutte locali - il pero, il ciliegio, l'acero, il melo, il mandorlo, il noce, il rovere torrefatto per ottenere le tonalità più scure- e i legni più preziosi, spesso esotici, scelti da fra Raffaele per il leggio confermano la duplice attribuzione al complesso ligneo di Rodengo.

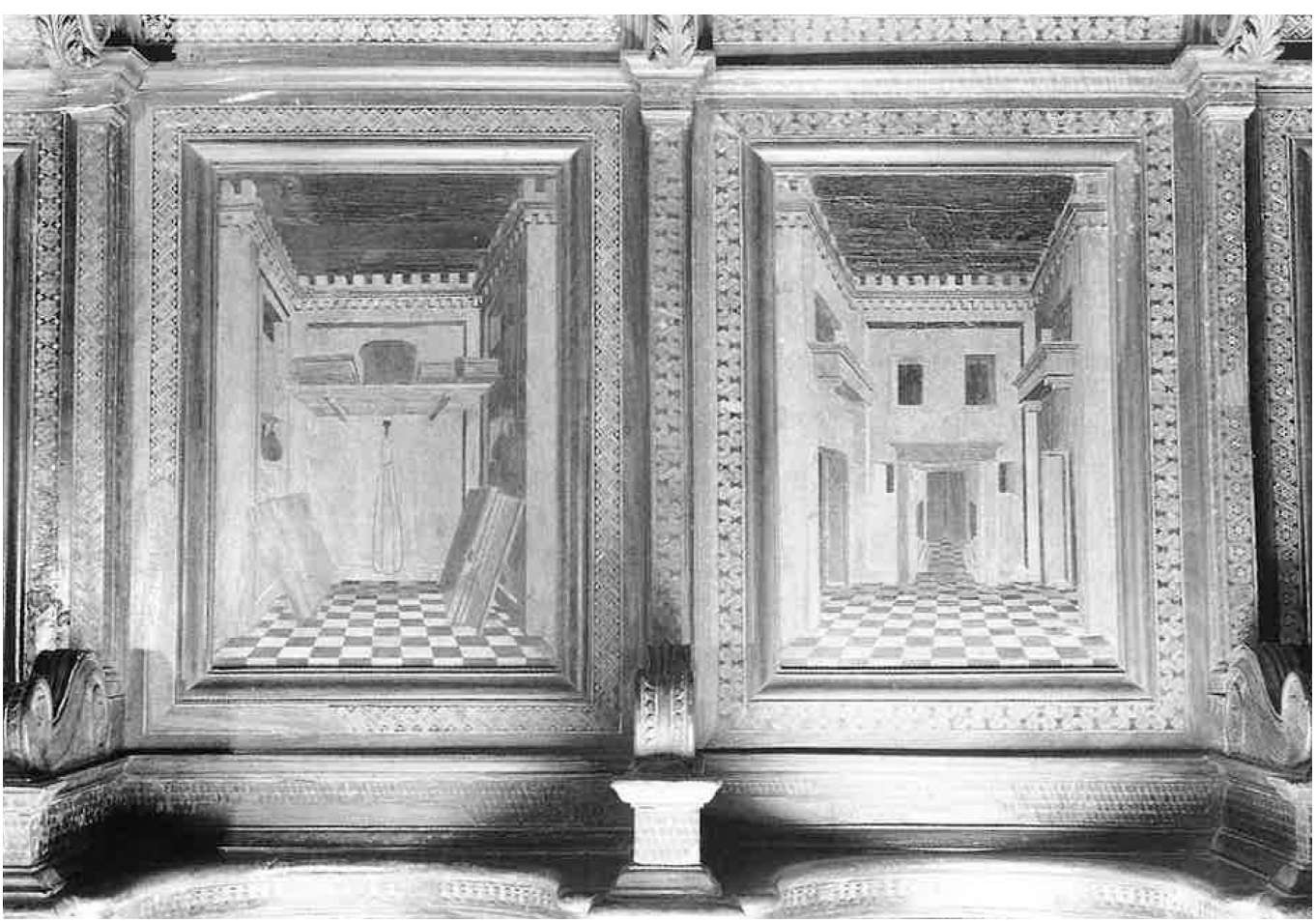

\section{Le tarsie del leggio}

I soggetti presenti nelle tarsie del leggio di Rodengo sintetizzano la varietà tematica presente nei principali complessi lignei, intarsiati e intagliati, del XV e XVI secolo. Delle quattro tarsie inferiori due rappresentano vedute prospettiche di edifici caratterizzati dall'uso degli ordini architettonici e architetture a pianta centrale [4], una terza è caratterizzata dalla presenza di un gatto accovacciato con un paesaggio connotato da rovine antiche ed infine nella quarta sono raffigurati libri, poliedri geometrici emblemi e simboli. (fig. 3) Le due specchiature triangolari della parte superiore sono connotate da due nature morte mentre le tarsie dei due piani inclinati di appoggio dei corali sono impreziosite dalla collaborazione di fra Raffaele con il pittore Girolamo Romanino (fig. 5).

I paesaggi con rovine e le architetture complesse a pianta centrale indicano una conoscenza del monaco bresciano dei canoni della nuova architettura importate a Venezia dal Sansovino e presenti, come già visto nei trattati di architettura mentre altri elementi fanno trasparire il gusto pittorico, cioè il desiderio di tradurre il quadro dipinto in tarsia.

La maggior parte degli studiosi [5] concorda nell'attribuire a Girolamo Romanino i disegni preparatori delle tarsie superiori del leggio raffiguranti scene di gentiluomini e di frati cantori.

Il controllo dello spazio prospettico nelle tarsie di fra Raffaele è simile a quello del suo maestro fra Giovanni [6]. 

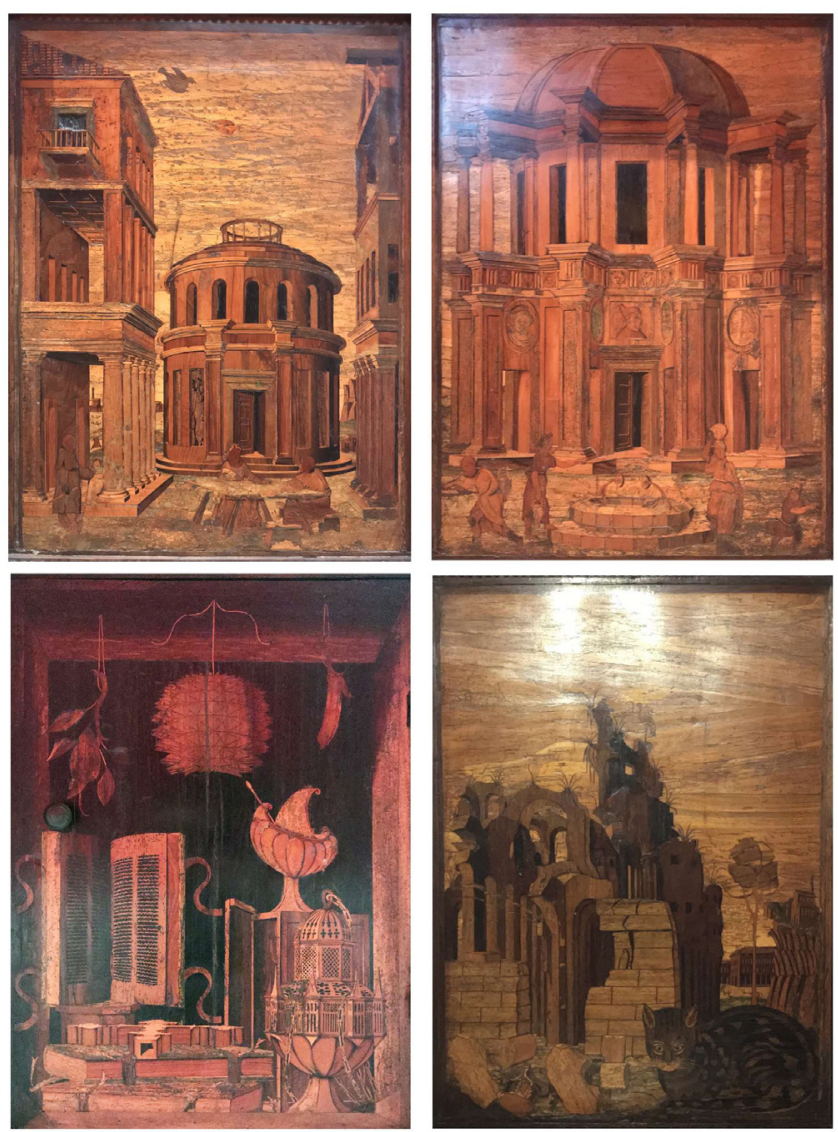

\section{Soluzioni d'angolo}

La differente forma dei badaloni - a pianta triangolare - di Verona e di Siena e - a pianta quadrata - di Rodengo genera diverse soluzioni angolari che testimoniano il lento passaggio da intagli prevalentemente decorativi utilizzati da fra Giovanni a cavallo fra XV e XVI secolo alla comparsa, a Monte Oliveto Maggiore, di lesene decorate nel I 519 da fra Raffaele, allievo di fra Giovanni ed infine all'utilizzo sapiente dell'ordine architettonico, nel primo Cinquecento, dimostrato dall'allievo bresciano affrancatosi dal linguaggio del maestro veronese [7] (fig. 4).

A Verona, nella chiesa di Santa Maria in Organo, "il badalone vero e proprio è magnificamente proporzionato rispetto allo sviluppo complessivo del leggio (3 metri circa), con la sua leggera complessione triangolare rimarcata agli angoli da agilissimi modiglioni scolpiti" [Bagatin 2000, p. 75] mentre nell'abbazia di Monte Oliveto Maggiore una semplice sequenza di tre lesene formano gli angoli smussati della parte inferiore, a pianta triangolare, del badalone che "alternativamente sviluppano candelabre con grottesche, mascheroni e decorazioni floreali e ripetono, in caratteri epigrafici, le iscrizioni: $F($ rater). $\mathrm{RAPH}($ ael). BRIXI(ensis). OPIFEX. F(rater). R(aphael). B(rixiensis). B(arnabae). A(bbati). G(enerali). R(everendissimo). P(atri). D(icavit), di dubbio scioglimento nell'ultima parte" [Brizzi 1989, p. I I7]. Le lettere $F$ - R - B - O sono intagliate, sempre da fra Raffaele, anche nella parte inferiore del badalone di Rodengo nell'ovale posto fra le colonne d'angolo (fig. 6) all'interno di un partito architettonico che testimonia la completa maturazione di fra Raffaele. Alla semplice sequenza di tre lesene decorate a candelabra e grottesche segue la perfetta articolazione di colonne scanalate e istoriate a evidenziare gli angoli leggermente aggettanti della parte inferiore del badalone intagliato come un vero e proprio modello ligneo di architettura. In sintesi, a Rodengo avviene una particolare contaminazione fra l'arte dell'intarsio, la pittura e l'architettura. 
Fig. 4. Lettura comparata fra tre leggii olivetani, da destra a sinistra:Verona, chiesa di Santa Maria in Organo, leggio di fra Giovanni, Abbazia di

Monte Oliveto Maggiore (Si) leggio di fra Raffaele (Si), leggio di ra Raf

(Bs), leggio di fra Raffaele

disegno e rilievo di

Massimo De Paoli).

Fig. 5. Tavole tratte dal trattato di Francesco

Giorgio Martini. Sono

evidenti i riferimenti alle

soluzioni architettoniche

realizzate per la prima

volta da fra Raffaele a

Rodengo.
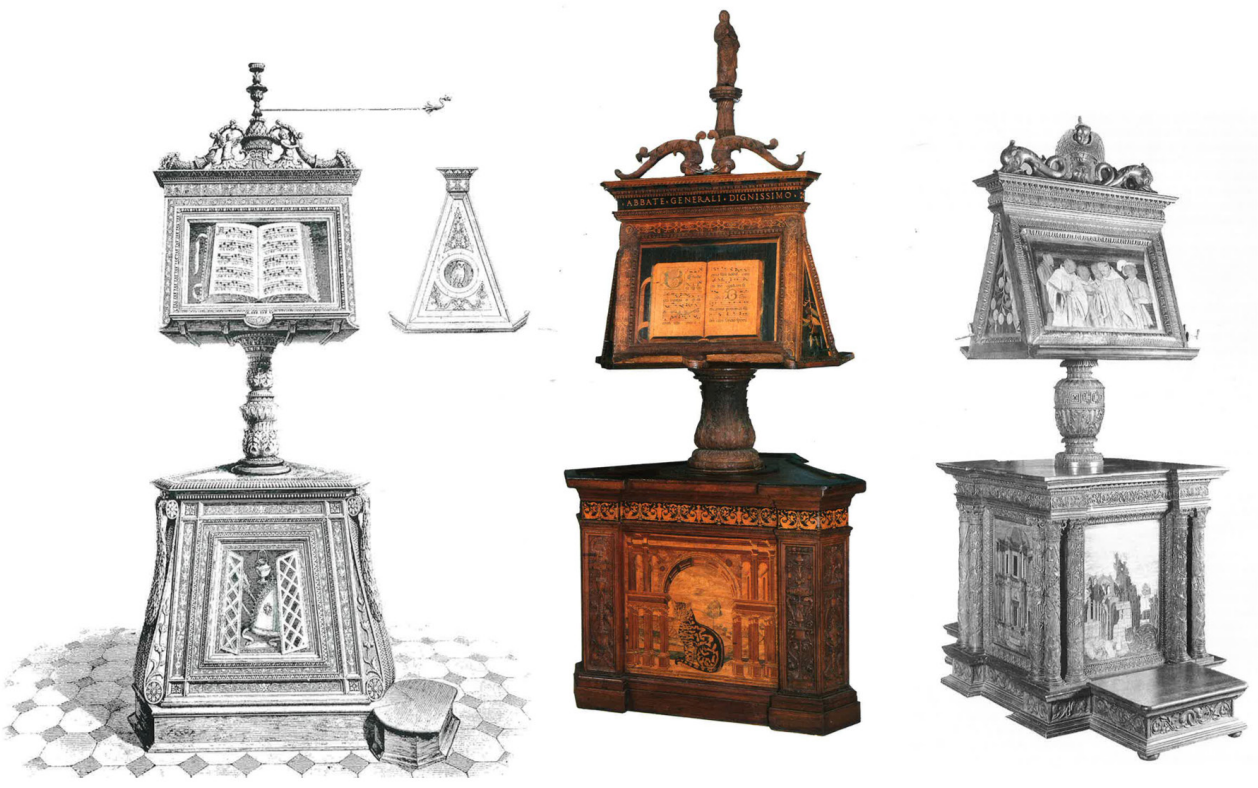
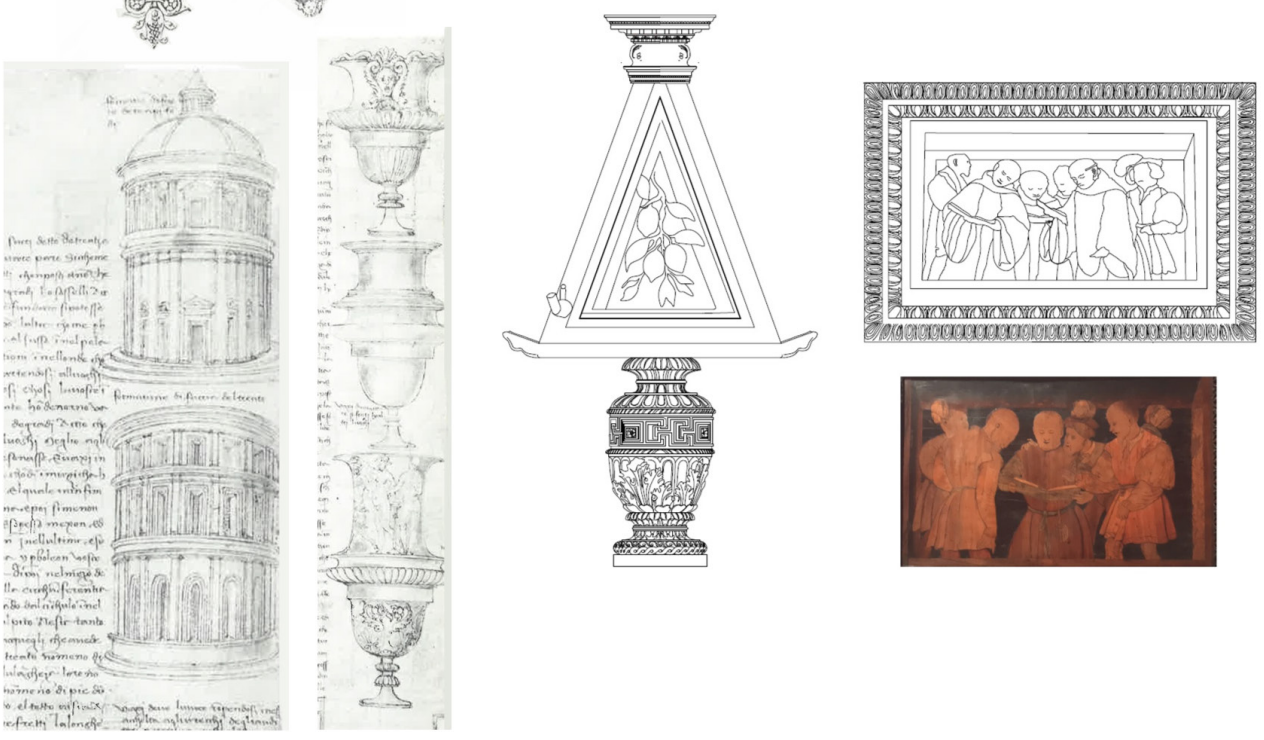
Fig. 6. Leggio di Rodengo, ora custodito alla Pinacoteca Tosio Martinengo di Brescia. A sinistra: pianta e alzato della parte inferiore del badalone e particolari degli angoli. A destra: in capitello della colonna capitelo della colonn storiata con la firma di a Rafaele, in basso, le te fra F. R. B. O intagliaA fra le colonne angolar. A destra: disegno del perno centrale intagliato e decorato a candelabra e particolare della tarsia superiore del leggio frutto della collaborazione tra Romanino e fra Raffaele (disegno e rilievo di Massimo De Paoli).
II sapiente utilizzo dell'ordine architettonico - la trabeazione a modiglioni con ovoli su dentelli nel sottocornice - testimoniano una maturazione ulteriore rispetto alle opere dei monaci olivetani di Verona, Bologna e Siena e una maggiore attenzione al dettaglio architettonico e non solo decorativo.

L'intaglio perfetto delle scanalature e delle colonne istoriate e il corretto proporzionamento dell'ordine completo sanciscono, nel badalone di Rodengo, il passaggio da un linguaggio prevalentemente decorativo e auricolare a una corretta applicazione dei principi architettonici codificati e custoditi nei trattati di architettura.

In alcune tavole del Trattato di Francesco di Giorgio Martini è possibile ritrovare alcuni temi e soluzioni tipologiche e formali presenti nel leggio di Rodengo. Le volute inverse che fra Raffaele utilizza per connotare ed evidenziare i capitelli delle colonne angolari istoriate, si pensi che in alcuni di questi il maestro bresciano intaglia la sua firma (fig. 6), sono del tutto simili alle volute utilizzate da Francesco di Giorgio nella tavola 227 del codice magliabechiano relativa alle forme di coronamento di trabeazioni e peducci, in particolare nel disegno di due gocciole per "il posamento di volte o in locho del chapitello" (fig. 5)

Anche il tema degli edifici a pianta circolare è ampiamente trattato nelle tavole | 30 e |3 | del codice torinese saluzziano 48 raffiguranti teatri e anfiteatri così come il motivo a candelabra presente nel perno centrale girevole del leggio di fra Raffaele è rintracciabile nel quarto trattato riservato ai Templi alle tavole 27 e 29 riguardanti i cimasi a vaso e alcuni particolari di fontane (fig. 5).
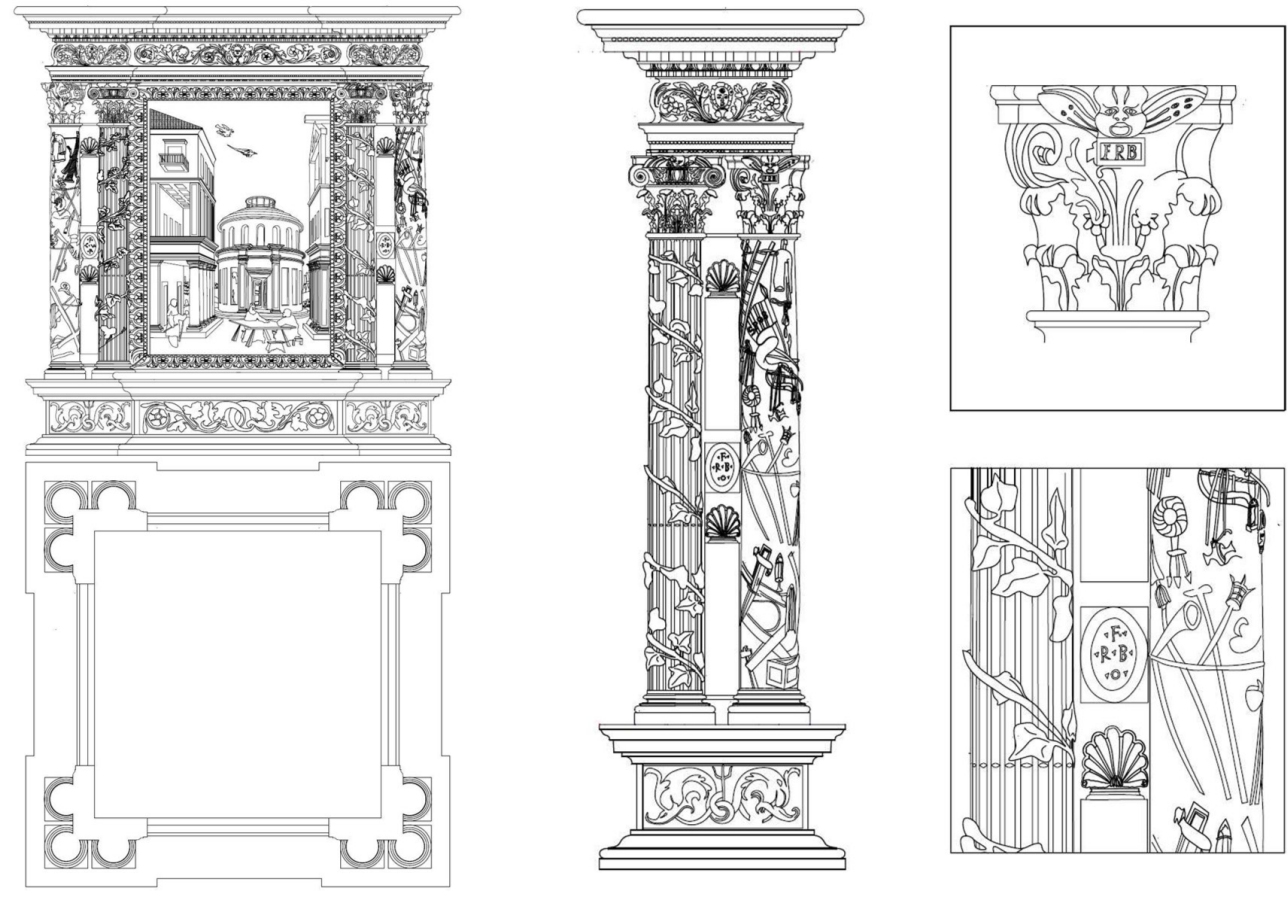

\section{II rilievo laser scanner 3d}

II rilievo geometrico del badalone esposto nella Pinacoteca Tosio Martinengo è stato eseguito mediante una Scan Station Leica P30 basata sulla tecnologia a tempo di volo. Lo strumento è dotato di un compensatore elettronico che assicura una volta messo in bolla la verticalità assoluta e possiede una portata di acquisizione fino a 130 metri, garantendo una elevata accuratezza e basso rumore in tutta la nuvola di punti con un'elevata risoluzione, che si attesta su $1.7 \mathrm{~mm}$ tra due punti posti alla distanza di 10 metri. 
Lo schema di acquisizione scelto sul posto è stato quello che permettesse l'acquisizione di tutti i dettagli strutturali e architettonici del badalone cercando di minimizzare i coni d'ombra generati dalla complessità decorativa e dalla ricchezza di particolari. Si è scelto di acquisire quattro posizioni diagonali a circa due metri da terra e a quattro metri dal badalone e otto posizioni (quattro diagonali più quattro in posizioni mediane dei prospetti principali a circa due metri di distanza (fig. 7). Per necessità intrinseche alle successive elaborazioni, unione tra le due nubi mediante algoritmo ICP di riconoscimento delle forme omologhe, è stata garantita una sufficiente sovrapposizione tra ogni ripresa e le successive che ricoprono le zone limitrofe; l'estensione della zona di sovrapposizione è diversamente quantificabile secondo la morfologia dell'area comune.

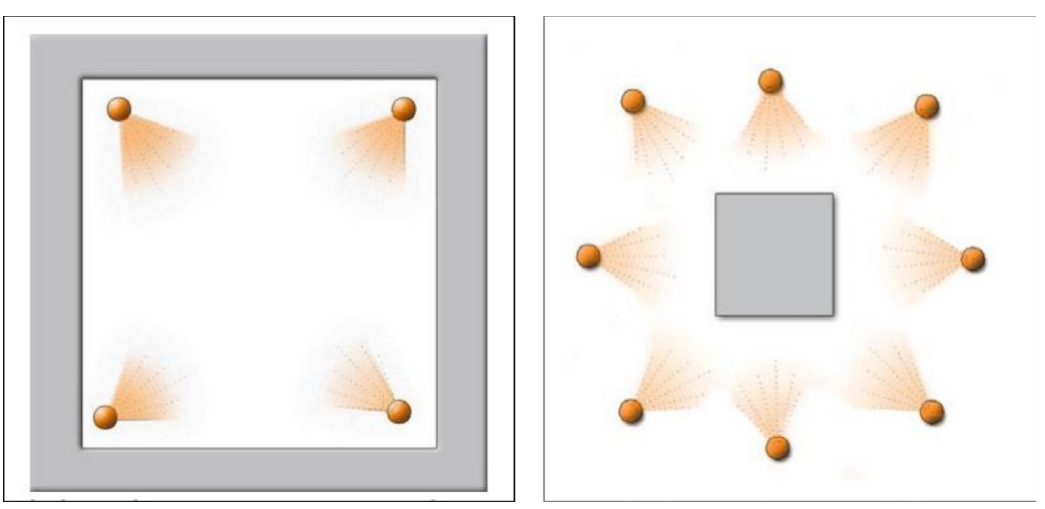

La tecnologia laser scanner 3D utilizzata è in grado di rilevare oggetti a scale e risoluzioni differenti, in tempi ridotti. Le sue caratteristiche principali riguardano la velocità di acquisizione e la versatilità delle applicazioni, adattandosi al rilevamento di piccoli manufatti. II laser scanner impiegato per il rilievo sfrutta la tecnologia della differenza di fase che calcola la distanza attraverso algoritmi specifici e consente di rilevare la misura tramite la differenza di fase tra l'onda emessa e quella ricevuta. Questi laser scanner sono particolarmente veloci ed hanno una griglia di punti molto densa. Una velocità tipica di questi scanner si attesta intorno al milione di punti/secondo. A ogni misurazione lo strumento rileva e memorizza le coordinate del punto collimato in un sistema di riferimento cartesiano ortogonale, per poi procedere all'acquisizione di un nuovo punto secondo una griglia proiettiva la cui la spaziatura è definibile in relazione al grado di dettaglio ricercato. II risultato del rilievo consiste in un database di coordinate tridimensionali di punti appartenenti alle superfici degli oggetti rilevati, visualizzabile in un ambiente digitale virtuale come un insieme di punti, denominato nuvola di punti, inseriti in uno spazio tridimensionale metrico.

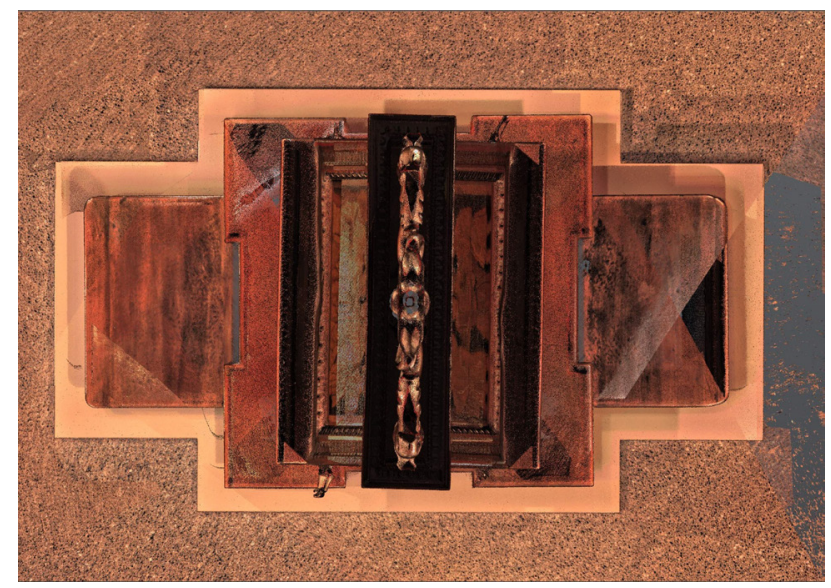


Al termine del rilievo, tutte le stazioni sono state collegate tra loro, e il software di gestione della nuvola dei punti ha generato in modo automatico un modello unico che può essere interrogato, sezionato e vettorializzato in un ambiente CAD.

Fig. 9. Leggio di fra Carnevale, rilievo laser scanner ortofoto, vista frontale.
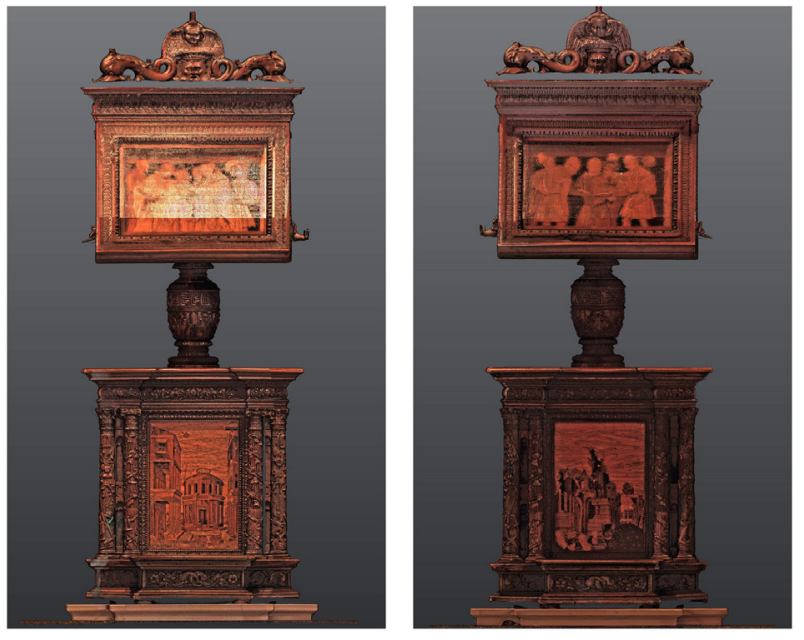

\section{Gestione del dato rilevato: registrazione delle scansioni laser scanner}

Terminato il rilievo e lo scaricamento dei dati dallo strumento, ogni scansione è stata inizialmente correlata a un sistema di riferimento con origine nel centro strumentale e orientamento casuale.

II trattamento delle singole nubi ha previsto la creazione, con un software specifico [8], del progetto nel quale sono state importate e decodificate tutte le scansioni effettuate. La fase successiva è consistita nella registrazione delle scansioni, vale a dire nell'unione in un unico sistema di riferimento cartesiano ortogonale di tutti i dati acquisiti.

La procedura di registrazione adottata si è basata sull'algoritmo ICP: in questa fase l'operatore ha il compito di analizzare le nubi per ogni coppia di punti di stazione (le due nubi devono avere almeno un 60-80\% di sovrapposizione), cercando tutte le forme omologhe e minimizzando i residui roto-traslando sul piano orizzontale e traslando su quello verticale una nube sull'altra. Ne è risultata una perfetta sovrapposizione delle due scansioni.

Infine, dal modello unito e texturizzato mediante l'RGB acquisito dal laser scanner sempre dal software utilizzato sono state estratte nove ortofoto ad alta risoluzione, ovvero viste ortometriche della nuvola di punti inquadrate in un sistema di riferimento locale e solidale al badalone (figg. 8- I2)

Tali viste sono i quattro prospetti principali, le quattro viste diagonali e la vista nadirale. Queste ortofoto sono diventate il supporto metrico per la successiva rappresentazione grafica.

\section{Note}

[I] Nel 1886 il Fè D'Ostiani nel suo volume sull'abazia di Rodengo dava l'opera a fra Raffaele, attribuzione che fu in seguito confermata dagli studiosi locali e perfino nell'Elenco degli Edifici monumentali edito nel 191 | I dal Ministero della Pubblica Istruzione. Si veda: Fè D'Ostiani Luigi Francesco ( ( 886), II comune e l'abazia di Rodengo, Brescia, Bersiana, pp. I I 40.

[2] Nel 1873 il Finocchietti nel suo lavoro sulla scultura in legno e sulla tarsia indicava Cristoforo Rocchi come autore del coro ligneo di Rodengo. Si veda: Finocchietti Demetrio Carlo (1873), Della scultura e tarsia in legno. Firenze:Tipografia Barbera, pp. I-319.

[3] Cristoforo Rocchi è noto per aver dato il primo modello ligneo del Duomo di Pavia e averne dirette le prime fasi costruttive dal I488 [Passamani 1980, pp. 93-100]. 

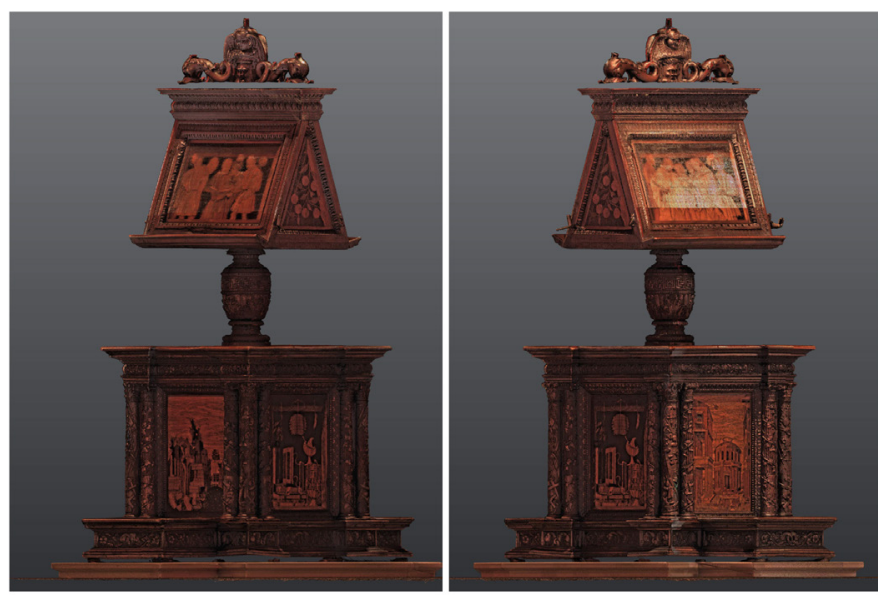

Fig. I I. Leggio di fra

Carnevale, rilievo lase

scanner, ortofoto, vista
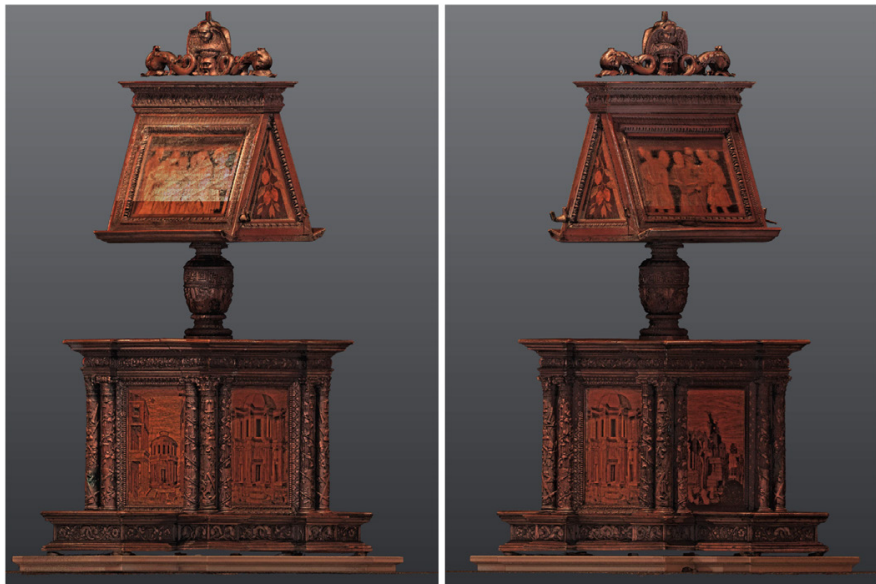

Fig 12. Leggio di fra Carnevale, rilievo laser scanner, ortofoto, vista laterale.

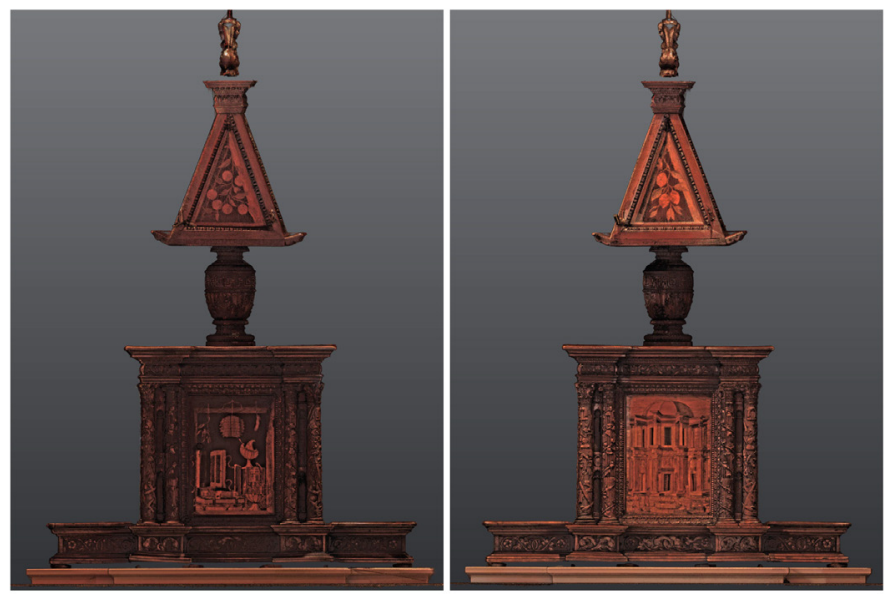


[4] Esplicito è il riferimento ad alcune tavole di edifici a pianta centrale del trattato di Francesco di Giorgio Martini. Nel medesimo trattato sono raffigurati anche capitelli compositi con volute rovesciate simili ad alcuni capitelli lignei angolari del leggio di Rodengo.

[5] Panazza ritiene che il carattere pittoresco di alcune tarsie inferiori del leggio di Rodengo, già presente nel leggio di Monte Oliveto, si arricchisca di una sensibilità quasi romantica frutto del contatto di fra Raffaele con la pittura di Lotto e Savoldo. Sempre lo stesso autore, in funzione dell'attività del Romanino nell'abazia di Rodengo propone una datazione al I529-30 per i disegni preparatori delle tarsie superiori del leggio, che precede di un lustro quella proposta dalla Ferrari (I 533-34): [Panazza 1965, p. 96; Ferrari 1961, pp. I-345]

[6] Si rimanda allo studio di Carlo Biagini per un'analisi esaustiva dei procedimenti prospettici sottesi alle tarsie di fra Giovanni nel coro di Santa Maria a Monte Oliveto Maggiore [Biagini 20 I 8].

[7] Anche per le tecniche artistiche e il partito decorativo Ferretti e Romano hanno evidenziato come fra Raffaello, sia ne coro di San Michele in Bosco che nel leggio di Monte Oliveto Maggiore, usa una tecnica e un repertorio diversi da fra Giovanni [Romano, Ferretti 1984, p. 283].

[8] Cyclone v 9.4.2.

\section{Riferimenti bibliografici}

Anelli Luciano (1987). S. Nicola di Rodengo. La chiesa dell'abazia. Brescia: Edizioni L'Ulivo.

Bagatin Pier Luigi (2000). Preghiere di legno. Tarsie e intagli di fra Giovanni da Verona. Firenze: Congregazione Benedettina di S. Maria di Monte Oliveto, Centro editoriale Toscano.

Bartoli Maria Teresa, Lusoli Monica (a cura di). (20 I 8). Diminuzioni e accrescimenti. Le misure dei maestri di prospettiva. Firenze: Firenze University Press.

Biagini Carlo (20 I8). Lo spazio prospettico nell'architettura delle tarsie di fra Giovanni a Monte Oliveto Maggiore. In Bartoli Maria Teresa, Lusoli Monica (a cura di). Diminuzioni e accrescimenti. Le misure dei maestri di prospettiva. Firenze: University press pp. $101-128$.

Brizzi Giovanni ( 1989). Il coro intarsiato dell'Abbazia di Monte Oliveto Maggiore. Cinisello Balsamo: Edizioni Amilcare Pizzi.

Ferrari Maria Luisa, (196|). I/ Romanino. Milan: Bramante editrice.

Ferretti Massimo ( 1982). I maestri della prospettiva. In Previtali Giovanni, Zeri Federico (a cura di). Storia dell'arte italiana, vol. XI, parte terza, vol. IV (Forme e Modelli). Torino: Einaudi, pp. 457-458.

Finocchietti Demetrio Carlo ( 1873). Della scultura e tarsia in legno. Firenze:Tipografia Barbera.

Francesco di Giorgio Martini. Trattati di architettura, ingegneria e arte militare. (Trascrizione di Livia Maltese Degrassi, 1967). Milano: Edizioni II Polifilo.

Innocenti Sereno (1997). Architettura e geometria. Lo spazio ritagliato. Le tarsie lignee e l'applicazione della prospettiva. Genova: Edizioni del disegno.

Panazza Gaetano (1965). Mostra di Girolamo Romanino. Catalogo. Brescia: Editore Industrie Grafiche Bresciane.

Passamani Bruno (1980). Le tarsie lignee del coro. In Anelli Luciano (1987). S. Nicola di Rodengo. La chiesa dell'abazia. Brescia: Edizioni L'Ulivo.

Passamani Bruno (1980). Le tarsie lignee del coro. In Atti delle "Prime giornate di studi" sulla storia dell'Abazia di Rodengo celebrative del XV centenario della nascita di S. Benedetto. Rodengo: Associazione Amici dell'Abazia di Rodengo, pp. 93 - I00.

Romano Giovanni, Ferretti Massimo (1984). Opere di tarsia. In AAV. La Basilica di San Petronio in Bologna. Cinisello Balsamo: Amilcare Pizzi editore, pp. 269-286

Thornton M. J. ( 1978). Three unrecorded panels by Raffaele da Brescia. In The Connoisseur, a. CLXXXXVII, N. 4, I978, pp. 240248.

\section{Autori}

Massimo De Paoli, Università degli Studi di Brescia, massimo.depaoli@unibs.it Luca Ercolin, Università degli Studi di Ferrara, lucaercolin@zening.it

Per citare questo capitolo: De Paoli Massimo, Ercolin Luca (2020). Il complesso ligneo dell'abbazia di Rodengo: il leggio di fra Raffaele/The wooden complex of Rodengo Abbey: the bookstand of friar Raffaele. In Arena A., Arena M., Brandolino R.G., Colistra D., Ginex G., Mediati D., Nucifora S., Raffa P. (a cura di). Connettere. Un disegno per annodare e tessere. Atti del $42^{\circ}$ Convegno Internazionale dei Docenti delle Discipline della Rappresentazione/Connecting. Drawing for weaving relationships. Proceedings of the 42th International Conference of Representation Disciplines Teachers. Milano: FrancoAngeli, pp. 2078-2097. 


\title{
The Wooden Complex of Rodengo Abbey: the Bookstand of Friar Raffaele
}

\author{
Massimo De Paoli \\ Luca Ercolin
}

\section{Abstract}

The Congregation of Olivetan monks also constituted - according to the Benedictine motto ora et labora - for many monks dedicated to woodworking, the occasion of apprenticeship in the art of inlay and carving: the learning of the foundations of this art (the choice of wood, its treatment with impregnating substances, the cutting and interlocking of laths, the use of mastics etc.) was the common denominator of each of them.

This is the red thread that binds Friar Sebastiano from Rovigno, Friar Giovanni, Friar Raffaele and all those who over time have enriched churches and abbeys with liturgical furnishings expertly inlaid and carved.

The given article offers a previously unknown architectural interpretation and 3D laser scanner survey of the Manuscript holder - work of frate Raffaele - inside Rodengo Abbey, currently kept in Tosio Martinengo Art Gallery in Brescia. The comparison between the Manuscript holder of Santa Maria In Organo Church in Verona, work of frate Giovanni master of frate Raffaele and the bookstand of Monte Oliveto Maggiore in Siena, carved and inlaid by apprentice from Brescia, points out similarities and differences between these two important olivetano works.

Keywords

bookstand, inlay, fra Raffaele, Congregation of Olivetan.

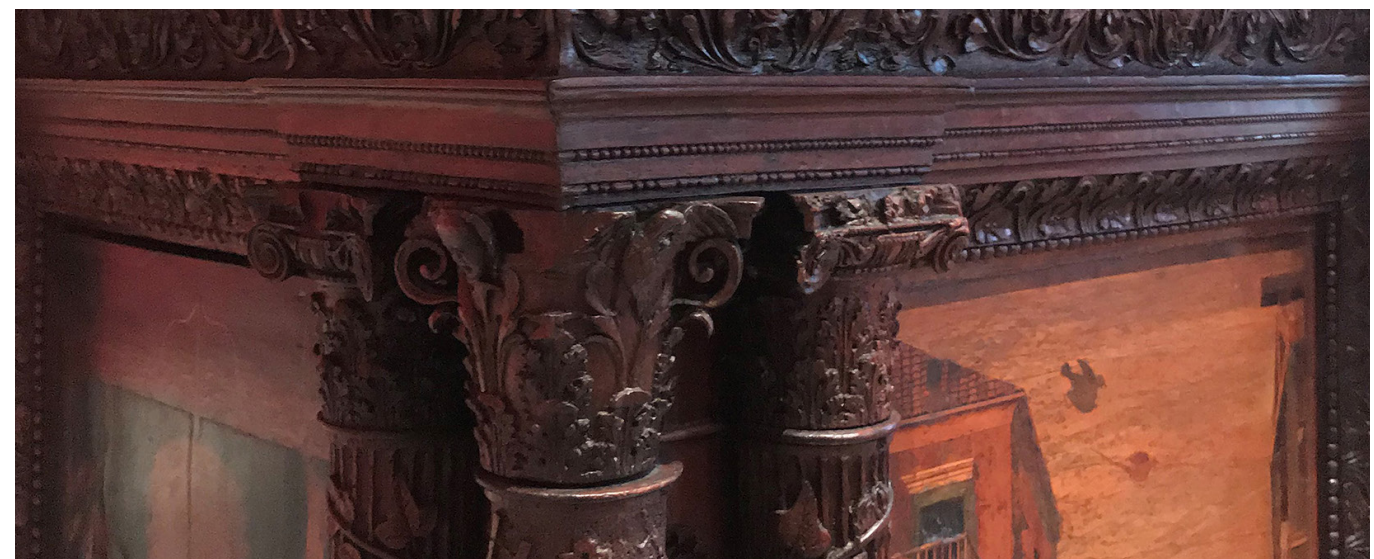




\section{The wooden choir and the bookstand}

The wooden complex of Rodengo was disassembled in the 19th century when the bookstand was sold to Brescia city council, in 1868, now it is kept in Tosio Martinengo Art Gallery. During the years of studying, especially locally, the choir as well as the bookstand [I] were attributed to frate Raffaele, and only in 1963 Lorenzoni focused his attention on what Finocchietti wrote almost a century before [2], and attributed the choir to Cristoforo Rocchi, a prestigious Ligneous Magister, meaning that he was the master of inlay, engraver and even carpenter and architect from Pavia [3].

The inlays of Rocchi's reredos show a certain "gap between the lines and the carved decorative elements similar to gothic and the architectures of inlaid cards that decorate the reredos" [Anelli 1987, p. 46]. The difference was probably caused by a drawing of the choir created by olivetan monks and delivered to Rocchi, as the documental sources witness in the analysis of Passamani, and a view of the master opposite to new canons of architecture. Passamani also claims that a rather high payment implies a participation in the project as well, and not only by a simple material rendition from drawing by Rocchi. The official explanation of decorated architectures in reredos proves the effort, of the artist itself as well as of the monks, in order to pass from rather ancient models supposedly represented in the olivetano monks' drawing to the more modern solution suggested by the master from Pavia. Rocchi, engraver and an architect as well, supposedly had given instructions at the end of I5th century, concerning the Manuscript holder, eventually realised by frate Raffaele.

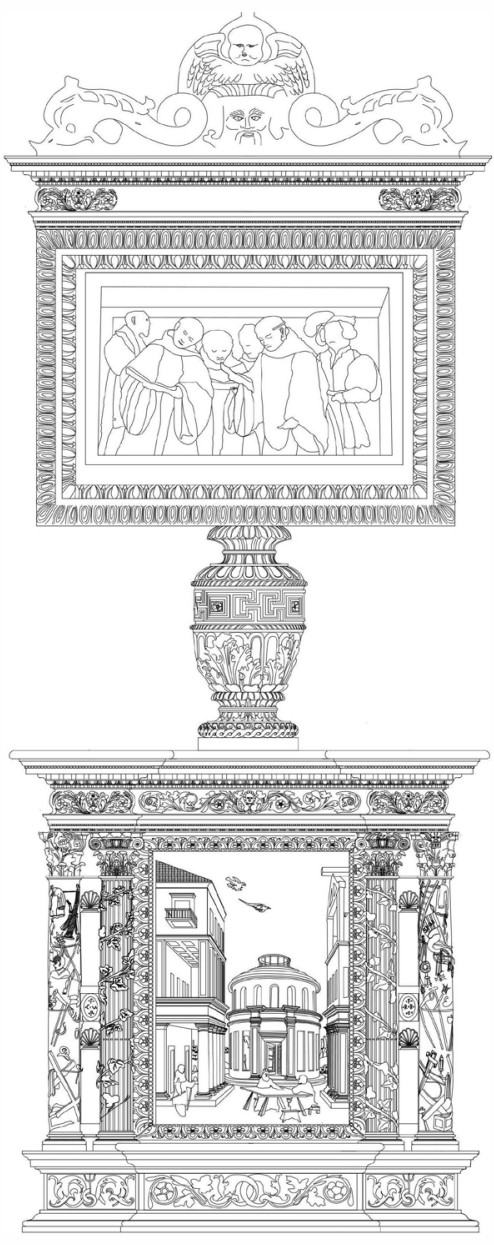


Strong features of Rodegno bookstand convinces to hypothesize an architect presence or precise indications concerning the use of architectural orders that were circulating in illustrated charts of treatise between I th and the beginning of I6th centuries, and constituted the formal catalogue by means of which each architect, sculptor, painter 0 artisan was developing new possibilities.

Even the difference between the wood used for inlays of choir - they vary but derive from local places - pear tree, cherry tree, oak, apple tree, almond tree, walnut, roasted durmast oak for the darker shades - as well as more precious wood, often exotic one, chosen by frate Raffaele for the bookstand, confirm the double attribution of wooden complex of Rodengo.

Fig. 2. Rodengo Abbey (Bs), San Nicola church, inlays of the choir of Cristoforo Rocchi.

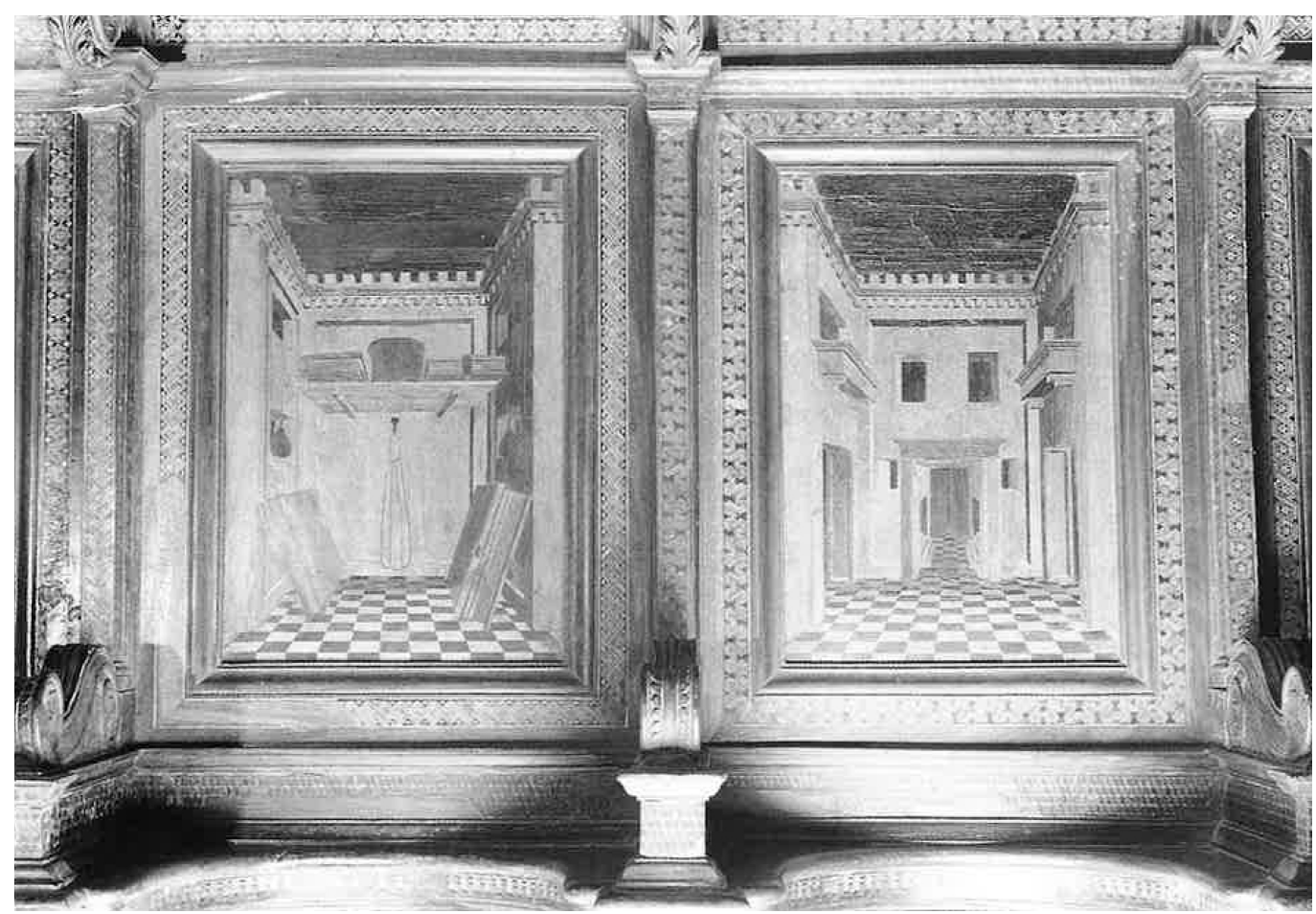

\section{Inlays of bookstand}

The themes present in bookstand inlays of Rodengo summarize the variety of topics presented in main wooden complexes, inlaid and carved of I5th and I6th century.

Out of four external inlays, two portray buildings' perspective views distinguished by use of architectural orders and central plan architectures [4], the third is characterized by the presence of a cat crouched and the landscape... and at the end in the fourth the books, geometric polyhedrons, emblems and symbols are illustrated.

Two triangle glass panels on the upper part depict two dead characters, while the inlays of two inclined surfaces of chorale stands are embellished as a result of collaboration between frate Raffaele and the painter Girolamo Romanino.

The landscapes with ruins and complex central plan architectures state the knowledge of a Brescian monk of new architecture rules imported to Venezia by Sansovino and as already seen, are present in architectural treatises while other elements show the pictorial taste, that is the wish to interpret a picture depicted with inlays.

Most scholars agree [5] to attribute the preparatory drawings of upper inlays of bookstand to Girolamo Romanino that illustrate the scenes of gentlemen and cantor monks.

The control of the prospective space in frate Raffaele inlays is similar to one of his master frate Giovanni [6]. 

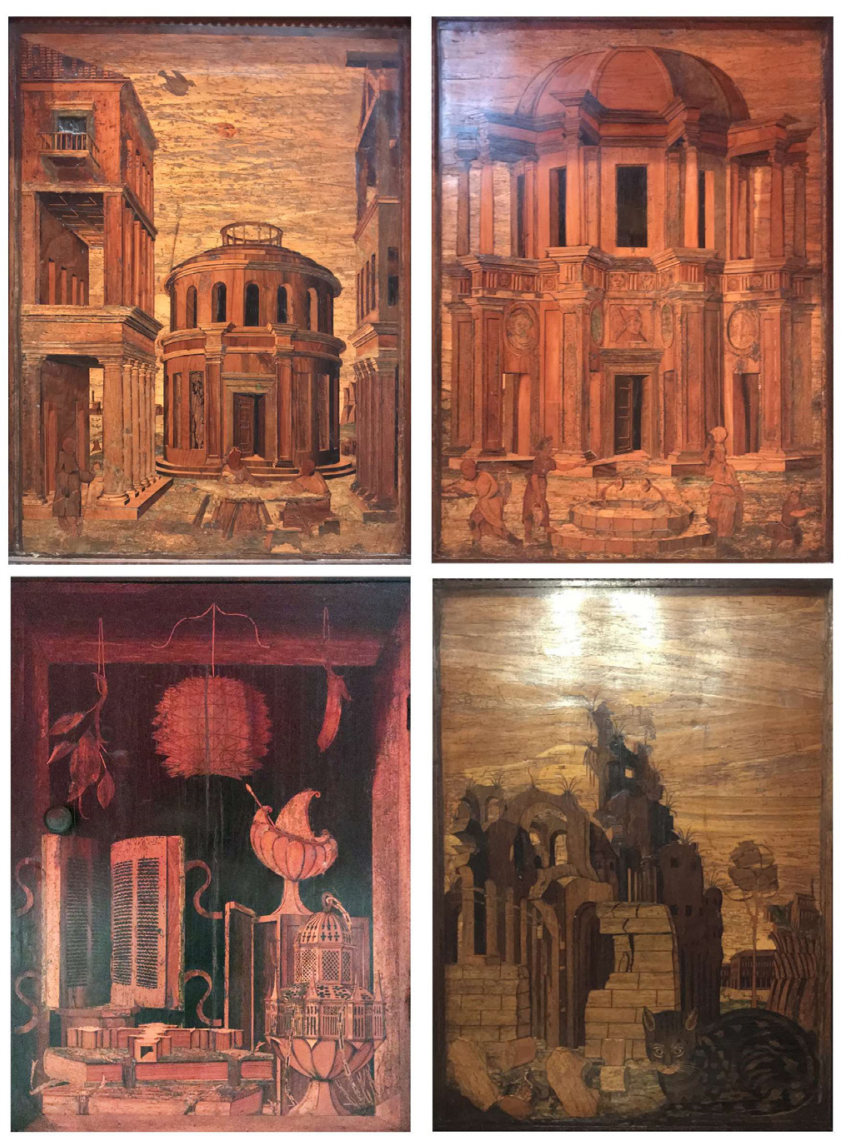

\section{The bookstand: angle solutions}

The different form of the manuscript holders - a triangle base - of Verona and of Siena, on the square base - in Rodengo generate various solutions for angles that prove slow transfer from carvings mainly decorative, used by frate Giovanni at the turn of 15th and 16th century, to the appearance in Monte Oliveto Maggiore of decorated half pilasters in 1519 by frate Raffaele, Brescian apprentice liberating himself from Veronese master's language [7]. In Verona, inside the church of Santa Maria in Organo, "the Manuscript holder itself is magnificently proportionate in relation to the overall extend of bookstand (apprx. 3 meters), with a slight triangular build distinguished at the angles by agile sculpted modillions, while in Monte Oliveto Maggiore abbey - a simple sequence of three half pilasters form the rounded angles of the lower part, a triangle base, of the manuscript holder that "alternately form candelabra with grotesques, masks and flower decorations which repeat in the epigraphic characters the inscriptions: F(frater). RAPH(ael). BRIXI(ensis). OPIFEX. F(rater). R(aphael). $\mathrm{B}$ (rixiensis). B(arnabae). A(bbati). G(enerali). R(everendissimo). $\mathrm{P}$ (atri). D(icavit), to resolve the doubts of the last part" [Brizzi 1989, p. I 17].

The inscriptions F- R - B - O are carved as well by Raffaele, even on the lower part of the Manuscript holder of Rodengo in the oval positioned between the columns in the angle.

This architectural solution proves that frate Raffaele matured completely by putting three half pilasters decorated with candelabras and grotesques in a simple sequence, counterpose the perfect arrangement of fluted and grooved columns in order to underline the slightly prominent angles from the lower part of the Manuscript holder carved as a perfect example of wooden architecture.

Briefly, a peculiar contamination takes place in Rodengo between the art of inlay works, the painting and the architecture. 
Fig. 4. Comparative reading among three Olivetan lecterns, from right to left:Verona church of Santa Maria in Organo, lectern of Friar Giovanni.Abbey of Monte ectern of Friar Raffaele Rodengo Abbey (Bs), lectern of Friar Raffaele.

Fig. 5. Tables taken from Francesco di Giorgio Martini's treatise.

The references to

"architectural" solutions

are evident for the first

time between Friar

Raffaele and Rodengo

(drawing and survey by Massimo De Paoli).
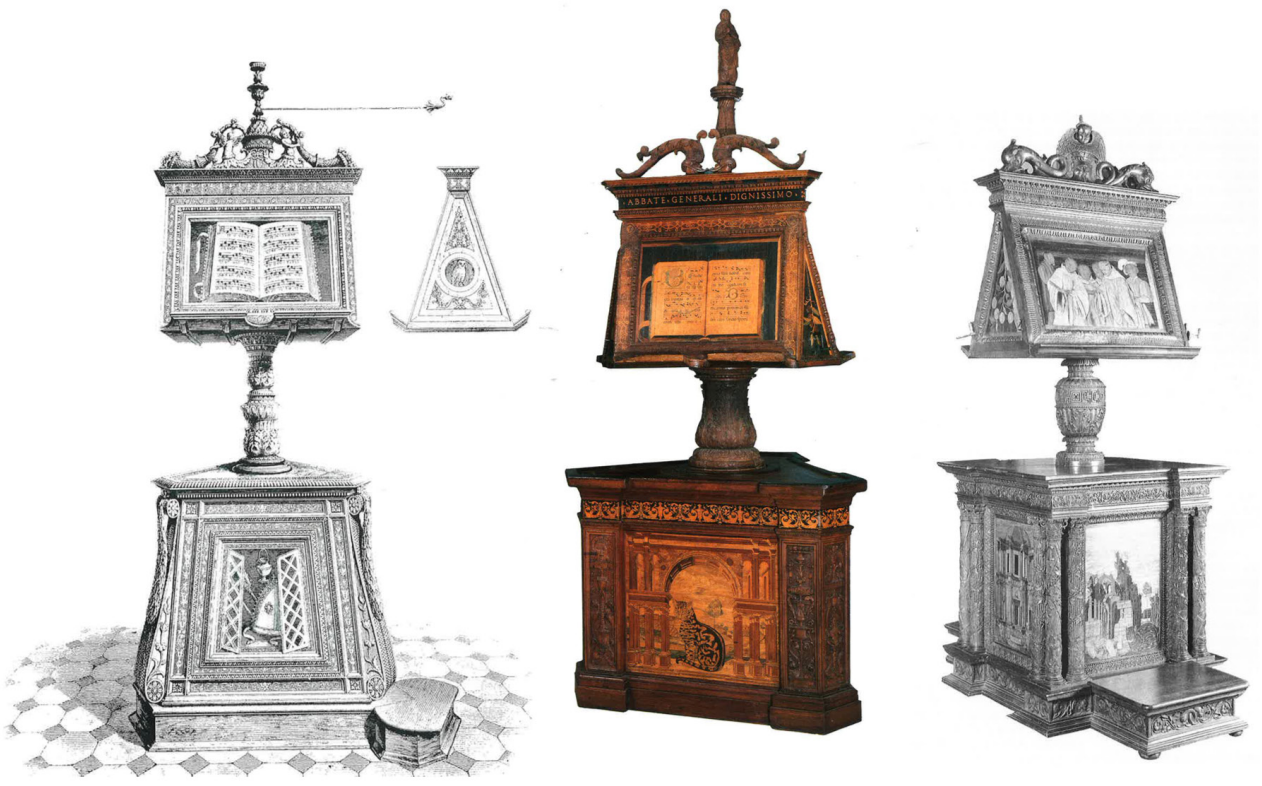
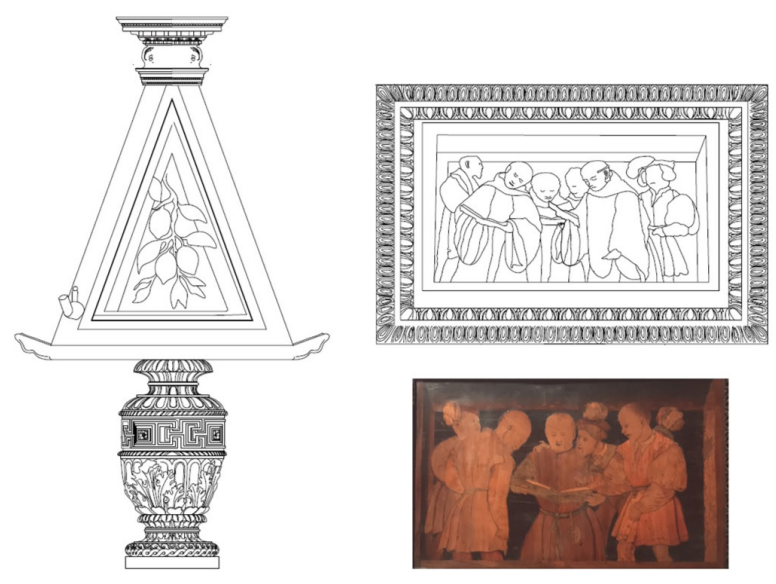
Fig. 6. Lectern of Rodengo, now kept in the Pinacoteca Tosio Martinengo Brescia. Left: plan and elevation of the lower part of the badalone and details of the corners.

Right: above, the capital

of the column decorated with the signature of Friar Raffaele; below, the letters F. R. B. O. carved between the corner columns. Right: drawing of the central pivot carved and decorated with a candelabrum and detal f the uppering of the of the upper inlay of the cetern, the result of the Romonino and Friar Raf Romanino and Friar Raffaele (drawing and survey by Massimo De Paoli)
The wise usage of architectural order - the entablature of modillions with ovolos on dentils on frieze - prove further progress in comparison with the works of olivetan monks from Verona, Bologna and Siena and major attention to details of architecture and not only decorative.

The perfect carving of flutes and of the grooved columns, the correct balance of complete order ratify in the manuscript holder in Rodengo, the transfer of predominantly spoken language to a correct application of architectural principles encoded and guarded in treatises of architecture.

In some tables of the Treaty of Francesco di Giorgio Martini it is possible to find some typological and formal themes and solutions, present in Rodengo's lectern. The reverse volutes that Friar Raffaele uses to connote and highlight only the capitals of the corner columns - consider the fact that in some of these these capital, the Brescian Master carves his signature - they are completely similar to the volutes used by Francesco di Giorgio Martini in table 227 of the Magliabechian code, relating to the crowning forms of the entablatures and corbels, in particular in the drawing of two drops for "the positioning of vaults or in locho of the chapitello".

The theme of the circular buildings is also widely covered in the tables I30 and I3 I of the Codex Torinese Saluzziano 48 representing theatres and amphitheatres as well as the candelabra motif in the swivel central lectern pivot of Friar Raffaele can be found in the fourth treatise reserved to the Temples at tables 27 and 29 concerning the potted cymases and some details of fountains
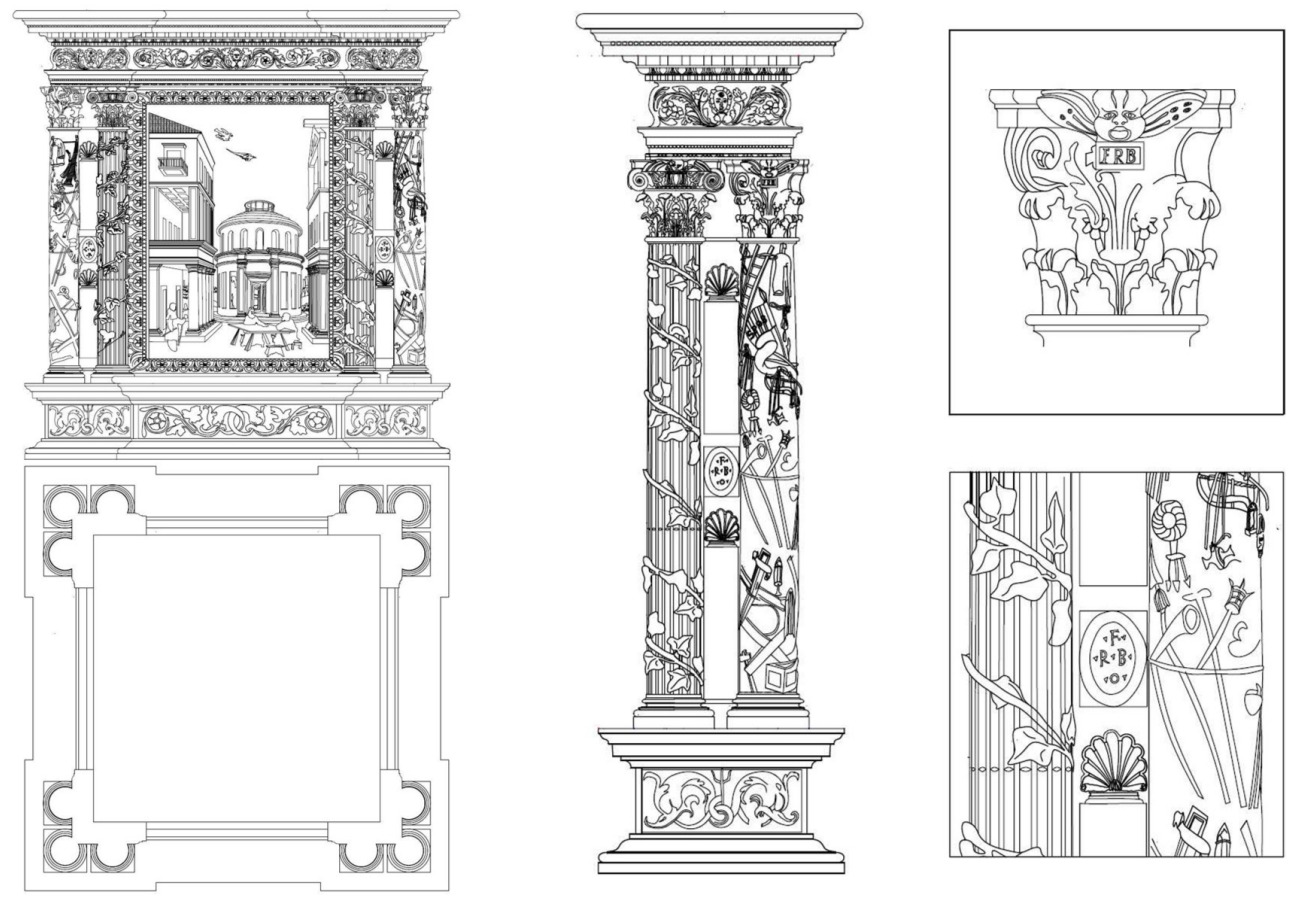

\section{Survey 3D Laser Scanner}

The geometric survey of Manuscript Holder represented in Tosio Martingegno Art Gallery was executed with the aid of the Scan Station Leica P30 based on the technology the Time of Flight.

The tool has an electronic compensator that ensures the absolute verticality once it was levelled out, and possesses an operational range up to $130 \mathrm{~m}$, guaranteeing high accuracy and low noise inside the entire cloud of points with high resolution, which is 1,7 $\mathrm{mm}$ between two points put at the distance of $10 \mathrm{~m}$. 
The data acquisition plan chosen on the spot was the one which permitted to capture all the structural and architectural details of the manuscript holder trying to minimise the shadow cones created by decorations complexity and abundance of details. It was chosen to take four diagonal positions approximately two meters above the ground and four meters away from the manuscript holder, and eight positions (four diagonal positions plus four in between positions of the main perspectives at approximately two meters distance.)

In order to help subsequent processing, merger of two clouds with the aid of ICP algorithm that recognises homological forms guaranteed the sufficient overlapping of each image and the others that cover the adjacent zones; the extension of overlapping zone is measured on the contrary according to the morphology common area.

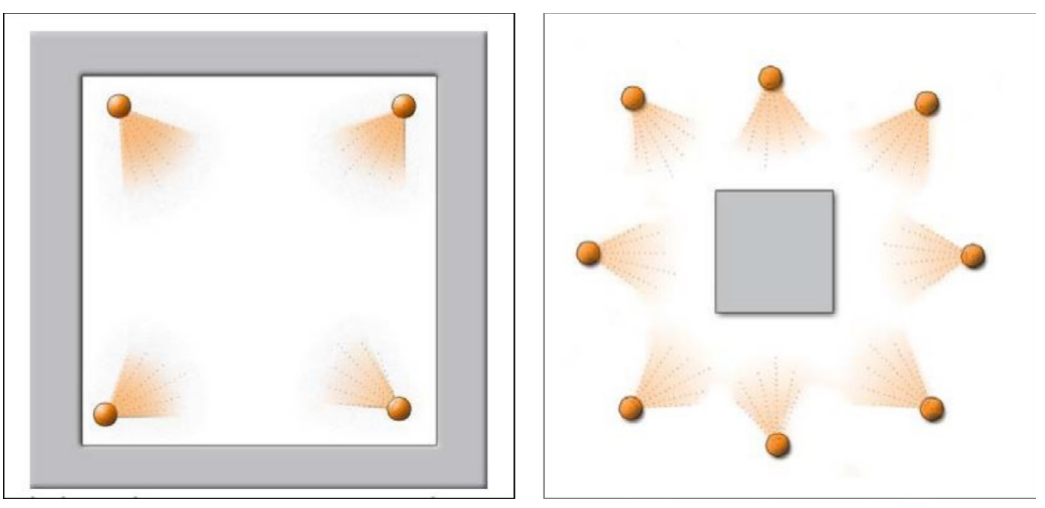

The 3D laser scanner technology is able to measure the scaled objects and with various resolutions in short period of time. Its main characteristics refer to the speed of scanning and the versatility of the usages, which can be adapted for scanning of small handiworks. The laser scanner used in survey elaborates the technology of the phases difference that, with the aid of specific algorithms, measures the distance and permits to measure the object based on the differences of phases between the wave emitted and the one received.

These laser scanners are quite fast and have a very dense point grid. The typical speed of these scanners proves up to 1.000 .000 points/second. The tool registers and records the coordinates of the collimated point inside the cartesian perpendicular reference system for every measurement, and then proceeds with measurement of another point according to the projective grid which gap is defined based on the level of details requested.

The result of the survey consists of the three-dimensional database of coordinates of the points belonging to the surfaces of the measured objects, these points are visible in a digital virtual environment as a whole of points, named as a cloud of points, inserted in a three-dimensional metric space.

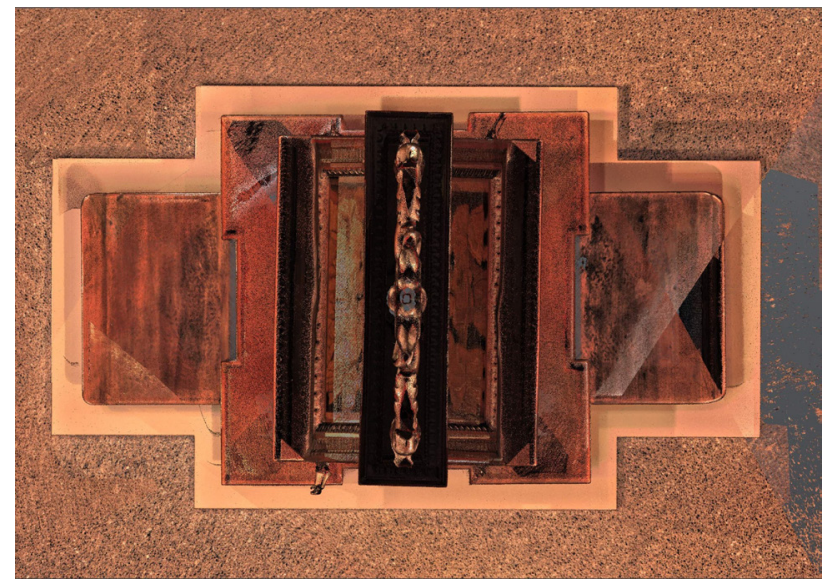


At the end of survey, all the stations are connected between them, the operational software of cloud of points will automatically generate a unique model that can be questioned, sectioned, vectored in CAD program.
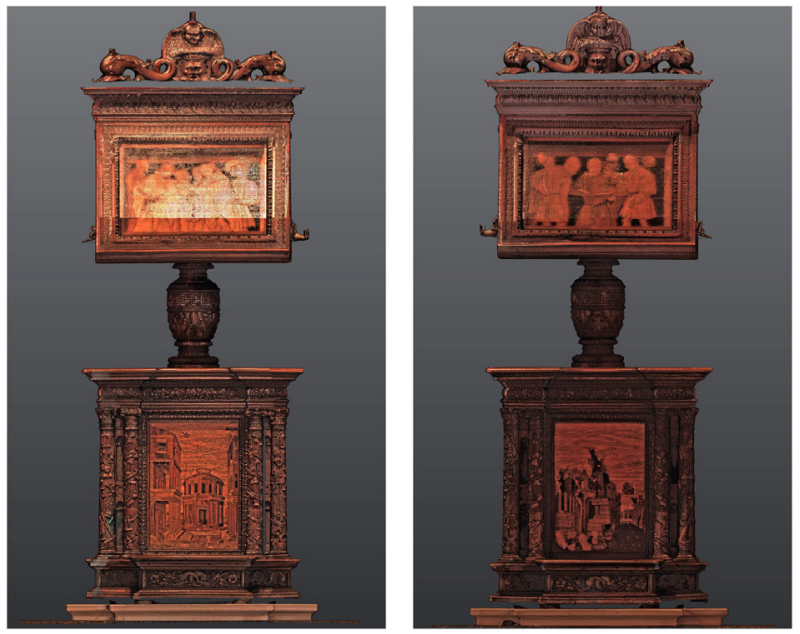

\section{Collected data utilization: Laser scanner scans registering}

Upon finishing collection and download of the data from the tool, each scan is initially associated with the tool centred reference system and random orientation.

The processing of each cloud presumes the creation of a project with the help of a specific software [8] where all the scans are imported and decodified.

The next phase consists of scan registration, in a reference cartesian perpendicular system of all the acquired data.

The applied registration procedure is based on ICP algorithm: the operator analyses the clouds of each couple of points of the station (two clouds have to have at least $60-80 \%$ of overlapping), looking for all the homological forms and minimizing the remains by rotating it on the horizontal level and transferring one cloud over another on the vertical. It gives a perfect overlapping of two scans.

Lastly from united and texturized model with the aid of RGV acquired from laser scanner by means of used software, 9 high resolution orthophoto were extracted, in other words orthometric views of cloud of points placed in the local reference system and coherent with the manuscript holder.

These types of views were four main perspectives, four diagonal views and nadir point view. These orthophoto have become the metric support for the subsequent graphic representation.

\section{Notes}

[I] In I 886 Fè D'Ostiani in his volume about Rodengo attributed the work to frate Raffaele, attribution was lately confirmed by the local scholars and even in the List of Monumental Buildings published in 191 | by Ministry of Public Education.

[2] In 1873 Finocchietti named Cristoforo Rocchi as the author of wooden choir of Rodengo in his work about sculpture and inlaying. See: Finocchietti Demetrio Carlo (1873). Della scultura e tarsia in legno. Florence:Tipografia Barbera.

[3] Cristoforo Rocchi is known for creating the first wooden model Duomo of Pavia and for supervising the first building phases starting from 1488. See: Passamani 1980, pp. 93-100. 

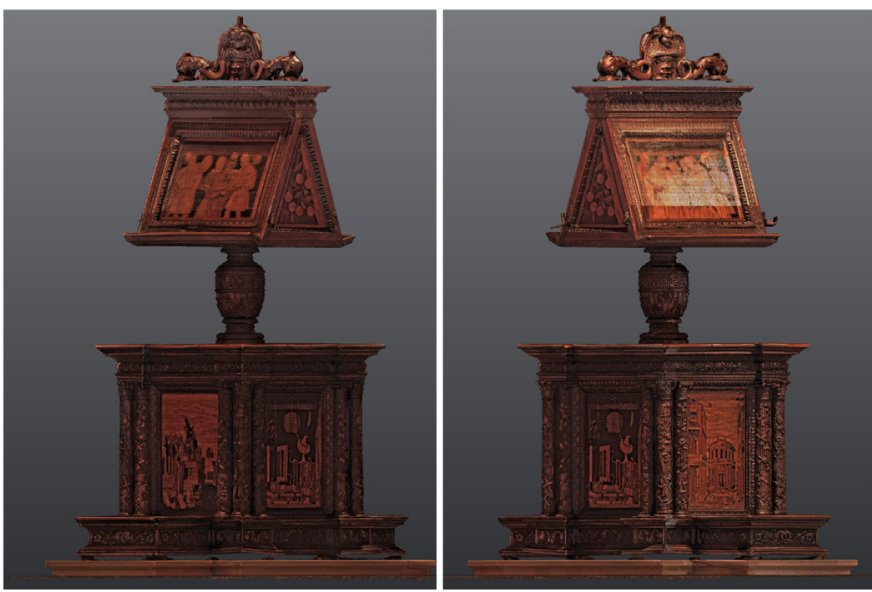

Fig. I I. Friar Carnevale's lectern, laser scanner

survey, orthophoto,
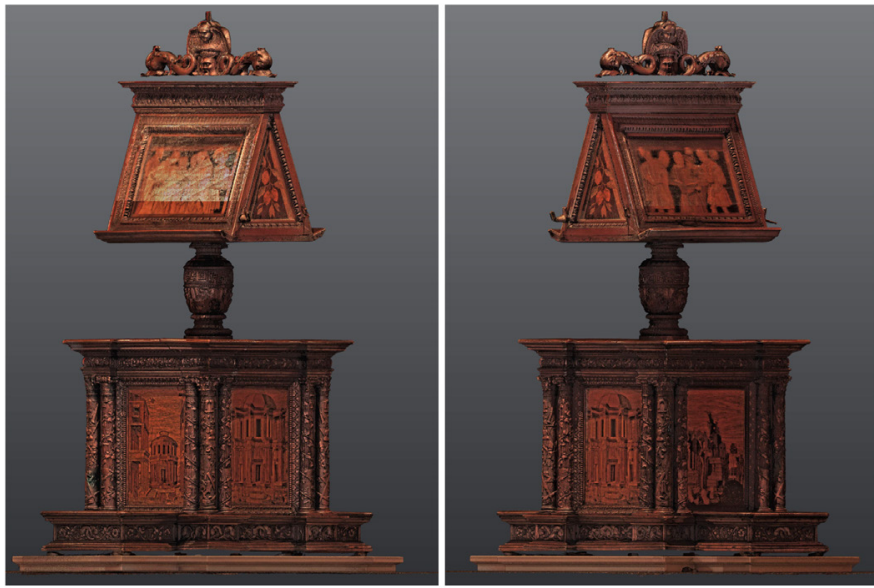

Fig 12 Friar Carnevale's lectern, laser scanner

survey, orthophoto, side
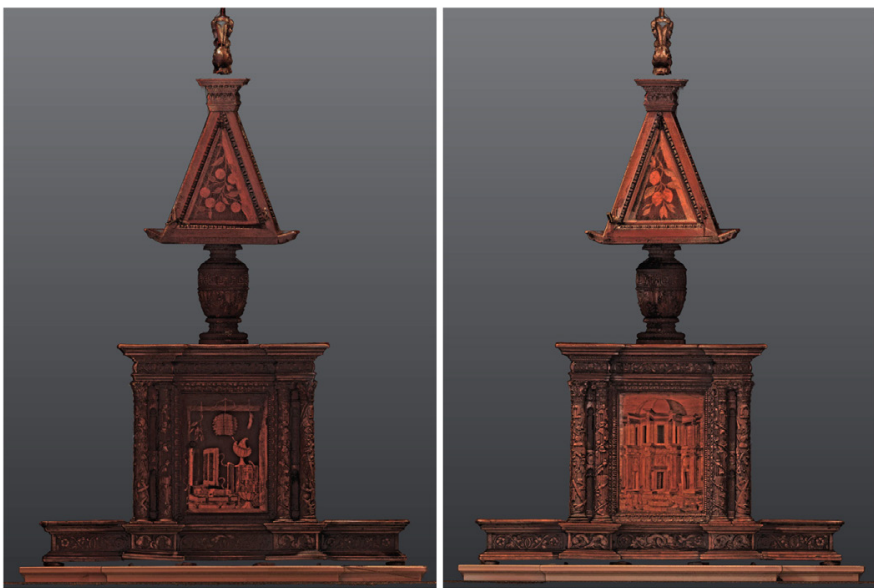
[4] Clear is the reference to some drawings of central plan buildings from the treatise of Francesco di Giorgio Martini. In the same treatise the composite capitals were illustrated with reversed volutes similar to some wooden capitals on the angles of bookstand in Rodengo.

[5] Panazza considers that the picturesque character of some of the Rodengo lectern lower inlays, already present in the Monte Oliveto lectern, is enriched with an almost romantic sensibility, resulting from the contact with Friar Raffaele and Lotto and Savoldo's paintings. The same author, according to the activity of Romanino in the Rodengo abbey, proposes a date of 1529-30 for the preparatory drawings of the upper inlays of the lectern, that is five years earlier than the one proposed by Ferrari (I533-34): [Panazza 1965, p. 96; Ferrari 196I, pp. I-345].

[6] Please refer to Carlo Biagini's study for an exhaustive analysis of the prospective procedures underlying the Friar Giovanni inlays, in the Santa Maria in Monte Oliveto Maggiore choir [Biagini 20 I8]

[7] Also with regard to the artistic techniques and the decorative elements, Ferretti and Romano have highlighted how Friar Raphael, both in the San Michele in Bosco choir and the Monte Oliveto Maggiore lectern, uses a dissimilar technique and a different repertoire from that of Friar Giovanni [Romano, Ferretti 1984, p. 283]

[8] Cyclone v 9.4.2.

\section{References}

Anelli Luciano (1987). S. Nicola di Rodengo. La chiesa dell'abazia. Brescia: Edizioni L'Ulivo.

Bagatin Pier Luigi (2000). Preghiere di legno. Tarsie e intagli di fra Giovanni da Verona. Firenze: Congregazione Benedettina di S Maria di Monte Oliveto, Centro editoriale Toscano.

Bartoli Maria Teresa, Lusoli Monica (a cura di). (20 I 8). Diminuzioni e accrescimenti. Le misure dei maestri di prospettiva. Firenze: Firenze University Press.

Biagini Carlo (2018). Lo spazio prospettico nell'architettura delle tarsie di fra Giovanni a Monte Oliveto Maggiore. In Bartoli Maria Teresa, Lusoli Monica (a cura di). Diminuzioni e accrescimenti. Le misure dei maestri di prospettiva. Firenze: University press pp. $101-128$.

Brizzi Giovanni ( 1989). Il coro intarsiato dell'Abbazia di Monte Oliveto Maggiore. Cinisello Balsamo: Edizioni Amilcare Pizzi.

Ferrari Maria Luisa, (196I). // Romanino. Milan: Bramante editrice.

Ferretti Massimo (1982). I maestri della prospettiva. In Previtali Giovanni, Zeri Federico (a cura di). Storia dell'arte italiana, vol. XI, parte terza, vol. IV (Forme e Modelli). Torino: Einaudi, pp. 457-458.

Finocchietti Demetrio Carlo (1 873). Della scultura e tarsia in legno. Firenze:Tipografia Barbera.

Francesco di Giorgio Martini. Trattati di architettura, ingegneria e arte militare. (Trascrizione di Livia Maltese Degrassi, 1967). Milano: Edizioni II Polifilo.

Innocenti Sereno (1997). Architettura e geometria. Lo spazio ritagliato. Le tarsie lignee e l'applicazione della prospettiva. Genova: Edizioni del disegno.

Panazza Gaetano (1965). Mostra di Girolamo Romanino. Catalogo. Brescia: Editore Industrie Grafiche Bresciane.

Passamani Bruno (1980). Le tarsie lignee del coro. In Anelli Luciano (1987). S. Nicola di Rodengo. La chiesa dell'abazia. Brescia: Edizioni L'Ulivo.

Passamani Bruno (1980). Le tarsie lignee del coro. In Atti delle "Prime giornate di studi" sulla storia dell'Abazia di Rodengo celebrative del XV centenario della nascita di S. Benedetto. Rodengo: Associazione Amici dell'Abazia di Rodengo, pp. 93- 100.

Romano Giovanni, Ferretti Massimo (1984). Opere di tarsia. In AAV. La Basilica di San Petronio in Bologna. Cinisello Balsamo: Amilcare Pizzi editore, pp. 269-286

Thornton M. J. ( 1978). Three unrecorded panels by Raffaele da Brescia. In The Connoisseur, a. CLXXXXVII, N. 4, I978, pp. 240248.

\section{Authors}

Massimo De Paoli, Università degli Studi di Brescia, massimo.depaoli@unibs.it Luca Ercolin, Università degli Studi di Ferrara, lucaercolin@zening.it

To cite this chapter. De Paoli Massimo, Ercolin Luca (2020). II complesso ligneo dell'abbazia di Rodengo: il leggio di fra Raffaele/The wooden complex of Rodengo Abbey: the bookstand of friar Raffaele. In Arena A., Arena M., Brandolino R.G., Colistra D., Ginex G., Mediati D., Nucifora S., Raffa P. (a cura di). Connettere. Un disegno per annodare e tessere. Atti del $42^{\circ}$ Convegno Internazionale dei Docenti delle Discipline della Rappresentazione/Connecting. Drawing for weaving relationships. Proceedings of the 42th International Conference of Representation Disciplines Teachers. Milano: FrancoAngeli, pp. 2078-2097. 